\title{
Women Participation to Sustain Environmental Development to Achieve the Millennium Goals Through Gender Equality and Good Governance
}

\author{
Uchechukwu Linda Anaeto
}

Angelina Oyibo Asoegwu

Faculty of Education Imo State University,

Owerri-Nigeria

\author{
Doi:10.5901/mjss.2013.v4n5p157
}

\begin{abstract}
This paper presents the highlights on how women participation in governance will sustain environmental development to achieve the millennium goals. It will include the gender equity and good governance for action. The study goes further to provide provocative insights on what action and reflection that should be followed to achieve this because equity. Mutualism, justice, self-reliance sustainability and peace are parts of the bedrock to achieve the millennium goals. However, in the past and even now, some women succumbed to the patterns enshrined by men which hinged on their domination of most of the environmental assignments and achievements whereas, the women have in their simplicity and innocence been interacting with the environment and the development process wherein, without realizing that they are the key and major player as in determining the future of the world; it is said, when a woman, is trained a nation is trained, this topic will be eruditely. Finally recommendations were made for a way forward.
\end{abstract}

\section{Introduction}

In the past and even now a lot of factors contributed to unsustainable environment of our nation. Corruption like lack of accountability and transparency and lack of knowledge in regulating the privatization process including lack of knowledge of regulating new investments. These elements involved high costs and incurred large public debts. Thus, through political patronage initiating a sense of complete injustice, incomprehensiveness, helplessness, poverty, inequality and causing insufficient and insecure technology and information systems to fall short of new demands, unsustainable and unrecoverable debts without the commensurate benefits

Asoegwu, (2006) pointed that, the disparity in the enrolment of males and females in Science Technology and Mathematics STM-education which is presently to the disadvantage of females is a matter of serious concern to science teachers, science educators, scientists and policy makers.

IFAD, (1978-2003) supported that, Women as agents of change within rural areas of developing countries, women generally constitute more than half of the population and considerably more than half of the agricultural labour force. They therefore represent a powerful force for economic growth. Notwithstanding this, women are often among the poorest people in rural areas. Indeed, one widely quoted estimate suggests that $70 \%$ of the World's poor are women. They are also disproportionately affected by HIVIAIDS. Their economic and social empowerment must be given high priority in poverty-reduction and economic development processes. In fact, the strategic role those women can play in rural poverty reduction is increasingly recognized, including in the millennium development goals (MDGs). IFAD's experience shows that support targeted at women yields significant returns, in terms of both increased incomes and overall household impact. 
Hence, Bella (1990s) recognized in women's attempts to conceptualize sustainable development, the recognition of the connections between the domination of nature and of women, provided important insights. Asoegwu, (2006) also observed that in the Geography class, 25 boys to 3 girls enrolled in 1990 WAEC it was only in Biology that females were up to $40 \%$ of the total enrolment in science subjects.

Furthermore, women's role is to influence, encourage and co-ordinate promotion of sustainable development, environmental protection, economic development, social development, equity. (There should be 50:50 representations of women and men in public appointments as to contribute in the decision making). A new strapline says, better for women, better for all, this is to demonstrate helping society as a whole, not seeing women as a marginalized group. This set out as new priorities to include:

(1) Stop violence against women

(2) Women drive forward initiatives to make real improvements to their lives

(3) Teenage girls who do well at school, out-performing boys but, often do not fulfill their potential (empowerment).

(4) Equity employment opportunities for men and women

(5) Eradicate extreme poverty and hunger from men and women

(6) Promote gender equality and empower women

(7) Combat HIVIAIDs, malaria and other diseases

(8) Achieving gender equity universal education from primary to tertiary

(9) Ensure environmental sustainability to men and women

(10) Dissemination of information to men and women

The above issues are crucial elements of any environmental sustainable development strategy for the millennium development goals. Obviously, for a significantly contribution to the achievement of the millennium development goals, these elements are to be emerged for discussion under two sub-headings:

(1) Ensuring environmental working sustainability in the development through gender, and

(2) How to promote women empowerment for good governance

The realistic evaluation to the exploitation of women knowledge must be developed, empowered and mechanisms identified to further the process. Then, clear opportunities should emerge for rewarding women good governance. Therefore, women should be fully involved in decision-making and in the implementation of sustainable development activities to achieve the millennium goals through gender equality.

\section{Ensuring environmental working sustainability in the development through gender equality}

The focusing needs of the environment should be enhancing telecommunications, infrastructure, transportation, technology, social-transformation of the surrounding, eradication of poverty and hunger, combat diseases, stop violence against women, improvement to women's lives, etc. all these to strengthen the capacity to meet quality and sanitary standards of the environment.

Although issues of development and the environment in general should be raised on the links between women, the environment and sustainable development. Moreover, these questions should intimate link between women and nature as a patriarchal, dominant rational subject (1) Are women and nature simultaneously subordinated by men drive for progress? Are women victims of the destruction of their environment due to men's domination? Are women the destroyer of the environment, that turned out to be the experts who are called to repair the damage? Are women simultaneously careers and victims because they are trapped in gender-based division of labour? Finally, how do these material conditions influence women's sense of their identify, especially their relationship with men to technology and development? These questions are the axis along which the structure of women and men, the environment and sustainable development through gender will be analyzed.

Obviously, the potential to seek for and act upon connections with other actors, such as environmentalists, ecologists and groups and movements that are critical of the dominant paradigm, and 
have an interest in participating in, transformations towards environmentally sustainable development. Alongside women expressing emancipatory visions for the future. Hence, the intervention and change that are crucial to the achievement of the millennium development goals should strengthening the capacity of the rural and urban areas and their organizations, improving equitable access to productive of natural resources and technology and also increasing financial services, economic opportunities, markets infrastructure, transportation and social services. However, lack of these social organizations make it difficult for the exploitation opportunities within the communities as to develop links with external partners. IFAD, (20022006)

IFAD, (2002-2006) pointed that; the main cause of entrenched poverty is lack of access to natural resources such as land, water and forests. Their inequitable distribution is often derived from long-standing historical and cultural practices. Moreover, the rural poor lack decision-making power over the use of these resources. Increasingly, land tenure systems, water rights and access by rural communities to forests and other common property resources are sources of social conflict. Reducing such tensions and improving planning for sustainable and equitable resource use are key challenges throughout the developing world.

Furthermore, there should be appropriate technologies and research to improve agricultural productivity through increasing returns to land and labour. Infact, as solutions are that technologies need to be developed through conducting and validating research with the collaboration of the existing risk-management strategies of small farmers. Also, these differ from men and women farmers and require equity gender approaches. Iheakaram, (2009) observed that, for, although the Obasanjo regime was itself steeped in corruption, it nevertheless decided to address the problem of poverty hence the establishment in 2001 of the National Poverty Eradication programme- NAPEP. Its principal objective was and is, to help eradicate extreme poverty by the year 2010, which is in accord with the Millennium Development Goal of the United Nations. NAPEP has developed the following schemes to help achieve its objective. (i)Youth Empowerment Scheme (YES) (ii)capacity Enhancement Scheme (CES) (iii)Community Enlightenment/Sensitization Scheme (COMESS) (iv)Social Welfare Service Scheme (SOWESS) (v)Rural Infrastructure development Scheme (RIDS), and (vi)Natural resources Development and Conservation Scheme (NRDCC) Imo State, like other states, adopted the scheme under the name of poverty Alleviation Programma (PAP) and in conjunction with NAPEP, PAP has reached out to many people. Indeed, under the Achike Udenwa regime, thousands of men and women, trained in various crafts, received equipment and money to start their own businesses and thus be selfemployed. Then, lack of the above, is the failure of the investments that could yield challenges for the millennium development goals. These investments will reduce poverty and linked to a proper understanding of poverty processes that affect different groups of women as compared with men. At the end, gained insight will foster the conditions of gender equity through enhancing their productivity, output, incomes and overall growth.

Ensuring the availability of market through helping buyers and sellers to meet and develop business relations and information with one another. Abaulai and Delgado, (1995) pointed that, promoting the development of a conducive policy environment that reduces uncertainty, and facilitates both the efficient functioning of markets and private-sector participation in the various marketing activities. Thus, the emergence of appropriate and competitive services to producers for input supplies for agricultural products. Hence, structured to create opportunities to develop their potentials and defend their interests to conscious revision of elements of the international trade which could speed up progress towards physical infrastructure like roads and transportation to the achievement of the millennium development goals induce through active participation of women, not just valid, but essential for the future of the world.

The combat of HIVIAIDs, malaria and other disease through medication, normalization and free communication of human beings aimed at promoting the involvement of men and women to solve problems related to waste disposal, nuclear testing, sanitation, water, energy, the degradation of the environment on health and means of livelihood of the people and the effects of pesticide use to ensure that at least 90 percent of men and women have access to education, information and services necessary to develop the life 
skills required to reduce their vulnerability to disease infection. Asoegwu, (2005:1) stated that, on the global level, discharging nutrients from industrial agricultural or residential run off into lakes and coastal oceans, nuclear weapon testing and wars, which produce excess radiation, excess emission of carbon dioxide and carbon monoxide fumes from industrial plants, motor vehicles, gas-flaring etc. have led to human health problems and harmful changes in the Earth's climate such as global warming. Wendy, (2008) observed that, HIV infection rates in persons 15 to 24 years of age, with the goal of ensuring that by 2005 prevalence in this age group is reduced globally, and by 25 percent in the most affected countries, and that by 2010 prevalence in this age group is reduced by 25 percent (ICPD +5 Para 70$)$. All these, are to ensure gender equity which reach full potential through improvements in health. Hence. Achieving the gender millennium development goals that will help improve the status of women in welfare of their families, communities, countries and in the world at large.

\section{How To Promote Women Empowerment For Good Governance}

All countries should strive to ensure complete access to women education and employment opportunities to any level. Hence, both boys and girls as quickly as possible, be given gender equity education that enhances and strengthens policy dialogue and coordination of advance empowerment of women. This also eliminates all kinds of violence against women and ensures women's ability to control and negotiate equally with men on the legal rights to inheritance.

The significant contributions of women in academic circle are of direct relevance to their empowerment and good governance. Thus, these questions may intimate link between women and empowerment. Is it the ideological structure and philosophical under-pinning of subordination that needs to be criticized from the perspective as well as the development? What do they have to contribute to the analyzes of hierarchy and power in general in the issues related to development?

Abdulai and Delgado, (1995) pointed that achieving the millennium development goals requires a new partnership between developed and developing countries, based on sound policies, good governance at all levels and the rules of law. Each country has primary responsibility for its own economic and social development; and, in this regard domestic resources, national policies and national development strategies will play the key role.

Elaborating comprehensiveness of leadership to promote the economic, political and social transformation of the country through men and women's equity awareness of their mutual relations and seeking to enhance their understanding of how these relationships affect their livelihoods, creating enabling environment for good governance and investment development.

However, htt://www observed that it needs to ensure that all its women reach their full potential through improvements in health, education and employment opportunities and by abiding with all international commitments and instruments on gender equality, equity and human rights such as the African Union Protocol on the Rights of Women in Africa and the Convention on the Elimination of all Forms of Discrimination Against women. (CEDAW).

Abdulahi and Delgado, (1995) supported that, these coalition also constitute a significant advocacy forum for legislation and policies that adequately reflect the fact that investing in women and in closing gender gaps pays, not only in terms of the benefits it brings to women, men, households and communities alike, but also in term of impact on national economic growth. This undoubtedly leading to the achievement of gender millennium development goals in the country.

Women's roles and responsibilities in the global environmental movement, lifestyles, peace, capacity to organize, generate income and contribute in the decision making in their homes, communities, nations and international levels are being identified, described and closely analyzed, particularly in the epistemological studies of women academics for the well-being of ourselves and future generation. In addition, women's access to control over fundamental assets such as capital, water, forest resources and land which endorsed 
legal texts and community contracts to recognize women's development and empowerment as a value to society.

Badiane et al, (2002) supported that, major improvements are needed in basic rural infrastructure and services- principally water, health and education in order to alleviated women's work burden and pave the way for women to take advantage of development opportunities. Women's voice and choice in community affaires and public decision-making at higher political levels must also be expanded so that women can influence decision affecting their own lives and realize their potential as agents of change-bringing their knowledge and commitment to bear at the community level and beyond.

Thus, efforts to reduce poverty and women as passive recipients of services tailored equity asset building to women and men needs and aspirations and enhance and support them. Furthermore, since institutions are always the key service providers of economic and social empowerment for accelerating effective decentralization in the era of globalization which is a mindset of 'winners and losers' to a collaboration that exploits growth opportunities for all. Hence, necessitated an in depth understanding of the complexities of women as key agents to strengthening the capacity and organizations, improving equitable access to productive natural resources, technology and increasing access to investments, markets, financial assets, knowledge and research, such transformation is based on the aspiration of the change process. Iheakaram, supported that, the impact of NAPEP on the nation is, one must observe, a function of how much funds is made available to it.

In January 2008, for example, NAPEP, disbursed over N120 Million to Imo State SMEs and farmers. Later in the year, in November 2008, NAPEP, in conjunction with the small and medium Enterprises Development Agency, organized a five day "Entrepreneurship Training Scheme for SMEs and farmers in ImoState. The sessions were well attended. I believe that, with the caliber of personnel at the ImoState branch of NAPEP and at the state's poverty alleviation bureau, the fight against poverty can be won. I am particularly impressed with the whole hearted determination of the leadership of NAPEP in Imo State: they not only disburse funds but go on to monitor the application of the funds and how the businesses the funds are run-all to ensure the success of the SMEs. The fight against poverty is an on-going, if you live a continuing battle, requiring governmental commitment.

The essence of government is the well-being of the citizens; any government worth the name should be seen to be concerned about the welfare of the people. I am of the conviction that poverty and youth unemployment can be conquered. All it takes is honest leadership and sincere concern for the plight of the people. We have the money and the men to do the battle. The President and the vice President are chairman and vice Chairman respectively of NAPEP. They know the quality of staff they have. They men are eager to work and ought to be helped, enabled to work like Winston Churchill to the Americans, these men "will not fail or falter; they will not weaken or tire". Just give them the tool, the money and they will finish the job. This is what the Senate and the House should do-urge the president to release money to his people, and we will soon see a "New face" of Nigeria.

Obviously, this requires faster progressive improvements in the institutional capacity to plan, monitor, evaluate and promote good governance and an enabling policy to mobilize and suggest on how best women empowerment, governments, donors and civil society at large can work together to create jobs and reduce poverty in the millennium development goals. Finally, women have often played leadership roles, promoting an environmental ethnic re-cycling through clean air, freedom of dissemination of information, crucial thinking, insight, self-determination, respect for indigenous people respect for human rights and peace that produce the forward-looking strategies which is wider regarded as the birth place of global networks of women. Therefore, the number of women and men in public life should be 50:50 representation of gender equity as to enable women good governance influence, encourage, co-ordinate, cross-working and drive forward initiatives to make real empowerment to women's lives. 


\section{Conclusion}

Women participation towards the coming of a holistic and harmonious achievement of the millennium development goals through liberating the power and potential of women to achieve sustain environmental development and acknowledging the care and protection of the country. Thus, require women and men alike to sweep aside the barriers of gender to develop the nurturing and replenishing qualities that form the common humanity for good governance. Furthermore, women participation and theoretical can transform existing agendas and power relationships into an expanded vision of what must be done to create the conditions that empower the women to become agent of change to assure a peaceful, healthy, affordable and equitable country for ourselves and future generations. In addition, 50:50 representation of women and men in public appointments is a crucial recognition of the contribution women should make to decisionmaking to achieve the benefits of new technologies, information and communication for a significant improvement in the millennium goals through gender equality and good governance.

\section{Recommendations}

(1) There should be co-operation between governments, public, private, institutions and NGOs as to ensure that policy makers consider the impact on women at the earliest stage for participation in the decision-making process.

(2) There must be equity gender perspective in design of technology as to meet the women's need.

(3) There must be protection and use of women's knowledge especially on education and information.

(4) Women should be protected from environmental hazards when empowered as producers and consumers of environmental resources.

\section{References}

Abdulahi, A. and Delgado. C. (1995). "Re-establishing Agriculture as a Priority for Development Policy in Sub-Saharan Africa" Conference Proceedings. Washington, D.C.: International Food Policy Research Institute (IFPRI).

Africa. World Bank Policy Research Working Paper 2867. July. Washington, D.C.: World Bank.

Asoegwu, A.O. (2005). Introduction to Environmental Science for Tertiary Institutions Owerri, Grace of God Publishers.

Asoegwu, A.O. (2006). Gender Inequalities in Science. Technology and Mathematics Education. Some Methodological and Theoretical Issues. Gender and STM Education Series No.1, STAN Publishers Ibadan.

Asoegwu, A.O. (2006). Gender Inequality: Implications for Development of Geographical Education. NAWACS Journal Vol.1 No.1

Asoegwu, A.O. (2008). Strategies in Environmental Monitoring Nigeria Journal of Research and Production. Vol. 12 no. 1 Nigerian Researchers Forum.

Available at http://www.acdi-cida.gc.ca/agricultureconsultation

Available at http://www.adb.org/documents/reports/global-poverty/2001/gpr110.asp.

Available at http://www.adb.org/worldfoodsummit/english.

Badiane. O. Ghura. D. Goreux. L. and Masson. P. (2002). "Cotton Sector Strategies in West and Central Africa" World bank Policy research Working paper 2867. July. Washington, D.C. World bank.

Bella, (1990s) Women, the Environment and Sustainable Development.

Dowlah, C. (2004). Back Waters of Global prosperity Praeger. Westport, Connecticut, USA.

Economic Commission for Africa. (2004). Striving for Good Governance in Africa: Synopsis of the 2005 African Governance Report Prepared for the Africa Development forum IV. Addis.

IFAD, (2002-2006) IFAD's New Strategic Directions for Frame Work.

IFAD, (2003). Women as Agents of Change. Roundtable Discussion Paper for the Twenty-Fifth Anniversary Session of IFAD's Governing Council. Women Driving Change at Community Level. Rome: IFAD.

Iheakaram, A.E. (2009) How to Remove Poverty. Heartland News Paper,P.11 No. 9, September, 2009.

Reynolds, F. and Goldsmith, J.E. (2002). Women and Sustainable Development - from Local to International Issues.

Van De Sand, (2002). Human Rights and Empowerment.

Wendy, H. (2008). Gender, Environment and Sustainable Development. Lecture for Kansas city Summer School. 